Andrzej Jacek NAJDA

UKSW Warszawa

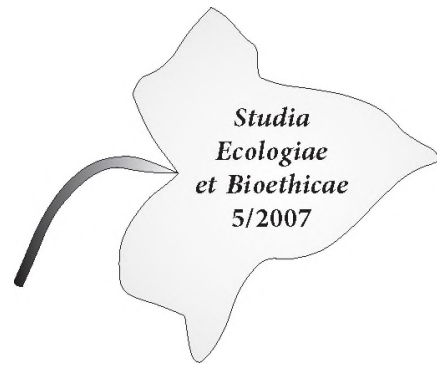

\title{
Ekologia w przypowieściach Jezusa
}

Pan Jezus w czasie swojej ziemskiej działalności „wędrował przez miasta i wsie, nauczając i głosząc Ewangelię o królestwie Bożym” (Łk 8,1), „lecząc wszystkie choroby i wszelkie słabości wśród ludu" (Mt 4,23). Koncentrował się przede wszystkim na nauczaniu (por. Mk 1,38: „Pójdźmy gdzie indziej, do sąsiednich miejscowości, abym i tam mógł nauczać, bo na to wyszedłem"). Przemawiając "do ludzi z krwi i kości”, w różnych okolicznościach, „dostosowywał sposób nauczania"1 do poziomu słuchaczy. Posługiwał się chętnie przypowieściami ${ }^{2}$, czyli opowiadaniami, w których „zestawia się, porównuje się ze sobą dwie rzeczywistości: religijną »rzeczową«, i wziętą z życia człowieka - »obrazową«, przy czym część rzeczowa, właściwa wypowiedź przypowieści, pozostaje najczęściej nie wyrażona. Słuchacz albo czytelnik sam musi się jej domyślić z części obrazowej”3.

\section{Forma przypowieści}

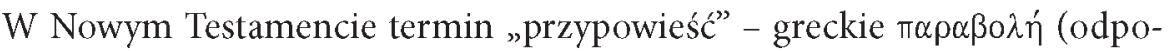

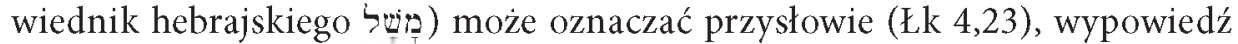
sapiencjalną (Mk 7,15), rozwinięte porównanie (Mk 13,28n), symbol (Hbr 9,9) oraz opowiadanie 4 . W świecie greckim przypowieści uzmysławiały prawdy lub rzeczywistości natury religijnej lub obyczajowej poprzez przykłady z natury lub z życia codziennego. W Piśmie świętym obrazy, metafory, porównania i przypowieści służą do takiego postawienia przed oczami słuchacza czy czytelnika nie-

\footnotetext{
R. BARTNICKI, Ewangelie synoptyczne. Geneza i interpretacja, Warszawa² 1996, 133.

2 Przypowieści są charakterystyczną formą nauczania Jezusa w ewangeliach synoptycznych, zaś w Ewangelii wg św. Jana występują mowy i dialogi objawieniowe. Por. S. MĘDALA, Ewangelie synoptyczne (Wprowadzenie w myśl i wezwanie ksiąg biblijnych 8), Warszawa 2006, 53.

3 A. Baum, Przypowieści, w: A. Grabner-Haider (red.), Praktyczny Słownik Biblijny, Warszawa 1994, 1092-1093, 1092; J.D. Crossan, Przypowieści, w: P.J. Achtemeier (red.), Encyklopedia Biblijna, Warszawa 1999, 1022-1024, 1022, określa przypowieści jako „krótkie opowiadania o podwójnym znaczeniu".

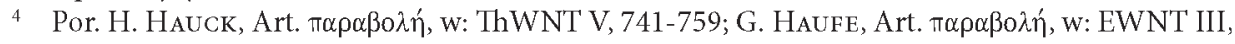
35-38; Por. także S. M̨̨DALA, dz. cyt., 53n.
} 
widzialnych rzeczywistości i religijnych prawd, których nie można wyrazić pojęciami, aby został on nimi dotknięty i wezwany do właściwego postępowania ${ }^{5}$. Pan Jezus nauczając w przypowieściach wykorzystywał je nie tylko do ilustracji trudnych prawd religijnych i moralnych, aby były zrozumiałe dla Jego słuchaczy, lecz także do ukrycia swego orędzia przed ludźmi wrogo do Niego nastawionymi. Przypowieści miały też wzbudzić zainteresowanie słuchaczy, aby treść Jego nauczania zapadała głęboko w ich serca. Poza tym forma przypowieści była bardzo pomocna w uczeniu się Jego słów na pamięćc.

Przypowieści Pana Jezusa można podzielić za A. Weiserem ${ }^{7}$ na przypowieści właściwe, które przedstawiają dobrze znane z życia codziennego i dlatego przekonujące sytuacje i doświadczenia. Do grupy tej należą między innymi przypowieści: o siewcy (Mk 4,3-9 i par.), o zaczynie (Mt 13,33), o zagubionej owcy (Łk 15,4-7) czy zgubionej drachmie (Łk 15,8-10) ${ }^{8}$. Drugą grupę stanowią parabole, które opowiadają o niezwykłych, szczególnych wydarzeniach, jak np. przypowieść o robotnikach w winnicy (Mt 20,1-16), o dziesięciu pannach (Mt 25,1-13) czy o synu marnotrawnym (Łk 15,11-32) . Trzecia forma przypowieści to opowiadania paradygmatyczne, które nie odwołując się do rzeczywistości religijnej opisują przykłady pozytywne lub negatywne, takie jak miłosierny Samarytanin (Łk 10,30-37), faryzeusz i celnik (Łk 18,9-14) czy zamożny człowiek (Łk 12,16-21) ${ }^{10}$.

We właściwych przypowieściach wyróżnić można dwie rzeczywistości: obrazową i rzeczową, które są sobie przeciwstawione. Rzeczywistość obrazowa przedstawia prawdziwe lub zmyślone wydarzenie z natury czy z życia codziennego człowieka, przy czym wszystkie obrazy i postaci zachowują swoje naturalne i właściwe znaczenie. Nie chodzi tutaj tylko o obraz czy zestawienie obrazów, lecz także o przebieg wydarzenia. Ważne jest przy tym, aby znaleźć jeden element, który jest wspólny dla wydarzenia z rzeczywistości obrazowej i dla wydarzenia z rzeczywistości rzeczowej - tzw. „tertium comparationis" ${ }^{11}$. I tak np. w przypo-

Tak O. KNOCH, Wer Ohren hat, der höre. Die Botschaft der Gleichnisse Jesu. Ein Werkbuch zur Bibel., Stuttgart ${ }^{2} 1985,10 \mathrm{n}$.

6 Por. R.H. STEIn, Przypowieści, w: B.M. Metzger - M.D. Coogan (red.), Słownik Wiedzy Biblijnej, Warszawa 1996, 667-670, 668.

7 Tak A. Weiser, Gleichnis. Neues Testament, w: W. Kasper i in. (red.), Lexikon für Theologie und Kirche IV, Freibur - Basel - Wien ${ }^{3} 1995,743-744$, 743. H.J. KLAUcK, Gleichnis, Gleichnisforschung, w: M. GöRG - B. LANG (red.), Neues Bibel-Lexikon I, Zürich - Düsseldorf $1991,851-856,852$, proponuje podział na porównania, metafory, słowa obrazowe, przypowieści właściwe, parabole, opowiadania paradygmatyczne i alegorie.

8 A. Weiser, dz. cyt., 743.

9 Por. C. Rose, Gleichnis, w: O. Betz - B. Ego - W. Grimm (red.), Calwer Bibel-Lexikon I, Stuttgart 2003, 448-451, 451.

10 Por. J. Roloff, Neues Testament, Neukirchen-Vluyn 1977, 94.

11 Por. H. Zimmerman, Neutestamentliche Methodenlehre. Darstellung der historisch-kritischen Methode, Stuttgart ${ }^{7} 1982,145$; R. BARTNICKI, Przesłanie Ewangelii, Warszawa 1996, 189. 
wieści o zagubionej owcy (Łk 15,4-7) jak cieszy się pasterz z odnalezienia zagubionej owcy, tak raduje się niebo, tzn. Bóg, z nawrócenia jednego grzesznika. Tertium comparationis jest w tym wypadku radość. Poprzez ogólne i każdemu znane prawdy, które są omawiane, przypowieści właściwe zyskują przekonującą siłę. Dlatego też rozpoczynają się często od słów: oủo€ic - „nikt” (Mk 2,21.22),

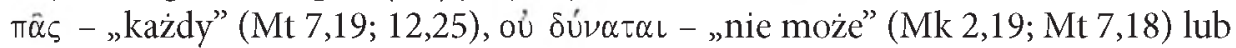

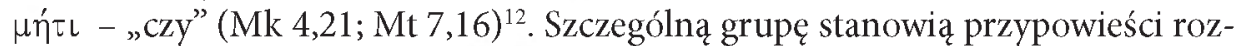

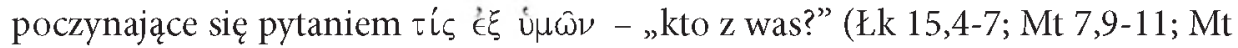
12,11; Łk 11,5-8; 17,7-10) ${ }^{13}$, na które oczekuje się odpowiedzi: „nikt” lub „oczywiście każdy"14.

\section{Ekologiczne obrazy w przypowieściach Jezusa}

Pan Jezus w swoich przypowieściach często posługuje się różnymi motywami i przedstawieniami ze świata przyrody, skąd czerpie inspiracje do nakreślenia rzeczywistości obrazowej. Na uwagę zasługują tu przypowieści o siewcy (Mk 4,1-9; Mt 13,1-9; Łk 8,4-8), o zasiewie (Mk 4,26-29), o ziarnku gorczycy (Mk 4,30-32; Mt 13,31n; Łk 13,18n), o chwaście (Mt 13,24-30), o nieurodzajnym figowcu (Łk 13,6-9), o figowcu (Mk 13,28-29; Mt 24,32-33; Łk 21,29-31), o przewrotnych rolnikach (Mk 12,1-12; Łk 20,9-19; Mt 21,33-46) i o robotnikach w winnicy (Mt 20,1-16).

\subsection{Przypowieść o siewcy (Mk 4,1-9; Mt 13,1-9; Łk 8,4-8)}

Ewangelista Marek rozpoczyna tą przypowieścią serię przypowieści o Królestwie Bożym (Mk 4,1-34). Ponieważ już w Mk 4,2 jest powiedziane, że Jezus „uczył wiele w przypowieściach" oraz w kolejnych wersach dołączone są słowa o celu i sensie przypowieści o siewcy $(4,10-12)$, jak również wyjaśnienie treści uczniom (Mk 4,13-20), przypowieść ta w zamiarze ewangelisty ma być paradygmatem właściwego rozumienia wszystkich przypowieści Jezusa ${ }^{15}$. Marek chce w ten sposób zapoznać czytelników z rodzajem przepowiadania Jezusa oraz zachęcić do jego przyjęcia, a także wskazać na los orędzia Jezusa wśród Żydów. Ewangeliści Mateusz i Łukasz przejmują tę przypowieść od Marka, podkreślając przy tym - tak jak Marek - ze uczniom „dana jest tajemnica królestwa Bożego" (Mk 4,11; Łk 8,10; Mt 13,11: „tajemnice królestwa niebieskiego") ${ }^{16}$.

12 Por. H. Zimmermann, dz. cyt., 145n.

13 Por. H. Greeven, „Wer unter euch...?“, w: Wort und Dienst, JThSB NF 3(1952), 86-101.

14 Tak J. Jeremias, Die Gleichnisse Jesu, Göttingen ${ }^{9} 1977,158$.

15 Tak O. KNoch, dz. cyt., 71.

16 Por. R. Pesch, Das Markusevangelium. Erster Teil. Einleitung und Kommentar zu Kapitel 1,1 - 8,26 (HThK.NT II/1), Freiburg - Basel - Wien ${ }^{5} 1989,237-240$. 
Przypowieść o siewcy jest przypowieścią właściwą, w której przedstawione są dwie sytuacje: zasiew i żniwo ${ }^{17}$. Przy sianiu nazwane są najpierw trzy przeszkody (Mk 4,4-7), które nie pozwalają wzrastać posianemu ziarnu: droga i ptaki, skalisty grunt i upał jak również dobra gleba z cierniami i ostem. Te trzy przykłady ${ }^{18}$ symbolizują wszelkie możliwe niebezpieczeństwa i przeszkody - opisane także czasownikami „wydziobać”, „przypalić się", „uschnąc”, „Zagłuszyć” - które sprawiają, że ziarno nie wydaje owocu. Przeciwnie do tego przedstawia kolejny wers $(4,8)$ los ziaren, które miały dobre warunki wzrastania. One „padły na ziemię żyzną i wydawały plon, wschodząc i rosnąc, a przynosiły plon trzydziestokrotny, sześćdziesięciokrotny i stokrotny". Sam siewca, który siejąc ziarno rozpoczyna proces wzrastania, spełnia w przypowieści rolę drugoplanową. Na pierwszym planie pozostaje los zasiewu i to jako całości, a nie poszczególnych ziaren ${ }^{19}$.

Jezus odwołuje się w tej przypowieści do przyrody, a konkretnie do ówczesnej sytuacji w Galilei, gdzie po wiosennych żniwach na przełomie maja i czerwca aż do czasu zasiewów w listopadzie lub w grudniu ziemia leżała odłogiem. Orki dokonywano najczęściej zaraz po żniwach. Przed sianiem ziarna nie orano, lecz dzielono leżącą odłogiem ziemię na części, które zaraz po zasianiu ziarna były orane, aby ptaki, przede wszystkim wróble, nie wydziobały zbyt wielu ziaren. Drogą zaś była wydeptana wśród pól ścieżka, którą także zaorywano. Kłos liczył wtedy przeciętnie 35 ziaren; nierzadko było to 60 ziaren, a w szczególnie dobrych latach nawet 100 . Potrójny plon nie był czymś niezwykłym (por. Iz 55,10n; Oz 10,$12 ;$ Ps 1,$3 ; 126,5 n{ }^{20}$. Przesłanie przypowieści sprowadza się do przeciwstawienia niepozornego, zagrożonego początku wśród trudności wielkiemu plonowi. Wprawdzie wiele ziaren przepada, ale te nieliczne, które padają na dobry grunt, przynoszą obfity plon. Mimo wszystkich niebezpieczeństw i przeciwności ziarna wzrastają i zasiew się opłaca. Plon przewyższa zasiew ${ }^{21}$.

Jezus opowiedział tę przypowieść pod koniec swojej działalności w Galilei, gdy wzmagał się w Izraelu, a przede wszystkim w ojczystej Galilei, opór kręgów religijnych i politycznych przeciw Niemu i Jego działalności ${ }^{22}$. Mówiono, że odszedł od zmysłów (Mk 3,21), że mocą Belzebuba wyrzuca złe duchy (Mk 3,22-27), że ma ducha nieczystego (Mk 3,30), odrzucono Go w rodzinnym Nazarecie (Mk 6,1-6),

17 Por. J. GnIlKa, Das Evangelium nach Markus. 1.Teilband. Mk 1 - 8,26 (EKK II/1), Zürich Einsiedeln - Köln - Neukirchen-Vluyn 1978, 158n.

18 Cyfra "trzy” jest symbolem „małej całości”, por. L. RYcken - J.C. WiLhoit - T. Longmann III, Słownik symboliki biblijnej, Warszawa 2003, 1026 n.

19 Por. R. Pesch, dz. cyt., 231-235.

20 O. KNoch, dz. cyt., 72n. Por. też C.S. Kelner, Komentarz historyczno-kulturowy do Nowego Testamentu, Warszawa ${ }^{2} 2000$, 89; J.I. PACKer - M.C. Tenney, Stownik tla Biblii, Warszawa 2007, 220-223.

21 Por. R. Kertelge, Markusevangelium (NEB.NT 2), Würzburg 1994, 46n.

22 Por. R. Pesch, dz. cyt., 225-227. 
chciano Go zgładzić (Mk 3,6). Na zarzuty wrogów, że początek Jego dzieła w Galilei jest tak mizerny, Jezus odpowiada właśnie przypowieścią o zasiewie i żniwie. $\mathrm{Na}$ przekór wszelkim przeciwnościom, co roku na nowo dokonuje się „cud żniwa”23, zasiew się udaje i przynosi obfity owoc. Tak samo będzie z królestwem Bożym, które mimo różnych trudności wyda plon w Izraelu i w calym świecie. Wykorzystując obraz z dziedziny przyrody Jezus wyraża również pewność, że zapoczątkowane przez Niego dzieło przezwycięży wszelkie trudności i właśnie dlatego, że początek jest tak zagrożony, żniwo będzie wielkie i wspaniałe ${ }^{24}$.

Wyjaśniając uczniom treść przypowieści o siewcy (Mk 4,13-20; Mt 13,18-23; Łk 8,11-15) Jezus przedstawia rzeczywistość rzeczową. Powie przy tym wprost, że "siewca sieje słowo" (Mk 4,14), a przywołując metafory ekologiczne użyte w przypowieści: droga, grunt skalisty, między cierniami, ziemia żyzna opisze dokładnie różne grupy ludzi słuchających tego słowa, do których się te metafory odnoszą ${ }^{25}$.

\subsection{Przypowieść o zasiewie (Mk 4,26-29)}

Przypowieść ta, należąca do grupy przypowieści właściwych, znajduje się tylko w Ewangelii wg św. Marka. Podobnie jak przypowieść o siewcy (Mk 4,1-9) unaocznia ona rzeczywistość królestwa Bożego wykorzystując do tego ekologiczne obrazy zasiewu i żniwa, które są sobie przeciwstawione ${ }^{26}$. Inny kontrast tworzy zachowanie człowieka, do którego ziemia należy i zachowanie zasianego ziarna. Gdy człowiek wrzuci tylko ziarno w ziemię, samo ziarno i ziemia dążą do żniwa, niezależnie od tego czy człowiek coś czyni, czy też nie. On nawet nie rozumie, jak to się dzieje. Jednakże nie samo wzrastanie jest uwypuklone w tej przypowieści, lecz siła, która nieodwołalnie wywołuje wzrost i żniwa ${ }^{27}$. Gdy ziarno zostanie wrzucone w ziemię, nikt nie może zatrzymać rozpoczętego procesu wzrastania, ponieważ sam Bóg tak ustalił, jak wskazuje na to cytat z proroka Joela $(4,13)$ kończący tę przypowieśćc ${ }^{28}$.

Dla człowieka antycznego naturalne procesy wzrastania i dojrzewania były zawsze nowym, zadziwiającym cudem Stwórcy. Jezus nawiązuje do tych procesów opisując swoją działalność. To On wrzucił nasienie w ziemię i w ten sposób rozpoczął istnienie i działanie królestwa Bożego, które wzrasta i dąży nieodwołalnie do osiągnięcia swojej pełni. Dostrzec to może tylko ten, kto pozwoli, aby Jezus otworzył mu $\mathrm{oczy}^{29}$. Chrystus znów sięga do metafor ekologicznych, aby udzielić odpowiedzi na

\footnotetext{
23 Tak O. KNOCH, dz. cyt., 73.

24 Por. J. GNilka, dz. cyt., 160n.

25 W relacji Mateusza $(13,18-23)$ mowa jest o pojedynczym człowieku, a nie o grupie ludzi.

26 Por. R. Pesch, dz. cyt., 255.

27 Por. O. KNOCH, dz. cyt., 85.

28 Por. J. Gnilka, dz. cyt., 183.

29 Por. C.S. Keener, dz. cyt., 90.
} 
pytania słuchaczy oraz na zastrzeżenia przeciwników, którzy wątpili w powodzenie działania Jezusa: Jak z takich skromnych początków, z działalności nieznanego człowieka z Galilei i z Jego nic nieznaczących zwolenników może powstać coś wielkiego, co objęłoby całą ludzkość? Jak zapoczątkowany przez Niego ruch miałby przemienić wszystkich ludzi i wprowadzić ich do królestwa Bożego? ${ }^{30}$

\subsection{Przypowieść o ziarnku gorczycy (Mk 4,30-32; Mt 13,31n; Lk 13,18n)}

Jest to kolejna przypowieść właściwa, w której Jezus mówi o królestwie Bożym ${ }^{31}$. Po raz kolejny posługuje się On znanym wszystkim obrazem ze świata przyrody, aby przedstawić rzeczywistość tego królestwa. Ziarnko gorczycy, gdy wsiewa się je w ziemię, jest najmniejszym ze wszystkich nasion. $Z$ tego ziarna wyrasta jednak krzew gorczycy, który jest większy od wszystkich innych roślin ogrodowych ${ }^{32}$. Krzew ten, który wyrasta w ciągu roku z ziarnka gorczycy, osiąga nad Jeziorem Genezaret od trzech do czterech metrów wysokości i jest wyższy od wszystkich podobnych roślin. W jego gałęziach ptaki, głównie zięby, budują gniazda ${ }^{33}$. Należy zwrócić też uwagę na słowa: „tak, że ptaki podniebne gnieżdżą się w jego cieniu", które przywołują starotestamentalny obraz potężnego królestwa, które daje swoim poddanym bezpieczeństwo i ojczyznę (por. Sdz 9,8-15; Ez 17,22-24; 31,1-9; Dn 4,10-12.17-23) 34. To królestwo ogarnia całą ziemię, na co wskazuje zwrot "ptaki podniebne" ${ }^{35}$.

Analogicznie do poprzednich przypowieści również tutaj Jezus przy pomocy przykładu z zakresu ekologii wskazuje na Boga. Jak zgodnie z Jego wolą z najmniejszego ziarnka gorczycy wzrasta największy krzew, tak niepozorne, historycznie mało znaczące działanie Jezusa utworzy królestwo Boże, które kiedyś obejmie cały świat ${ }^{36}$. Jezus jest Bożym Posłańcem, którego zadaniem jest zrealizować Boży plan zbawienia wszystkich ludzi. Obraz zaś królestwa, które daje schronienie i ojczyznę, wskazuje na rzeczywistość, która objawi się historycznie i będzie przemieniała świat ${ }^{37}$.

${ }^{30}$ Por. E. Schweizer, Das Evangelium nach Markus (NTD 1), Göttingen - Zürich ${ }^{17} 1989$, 51; O. Knoch, dz. cyt., 87.

31 Ewangeliści Mateusz i Łukasz, którzy przejmują tę przypowieść od Marka, wykorzystują też źródło Q, w którym ta przypowieść występuje razem z przypowieścią o zaczynie tworząc tzw. „podwójną przypowieść”. Por. R. Pesch, dz. cyt., 260.

32 Ewangeliści Mateusz i Łukasz określają ten krzew jako drzewo (Mt 13,32; Łk 13,19), aby jeszcze dobitniej podkreślić jego wielkość. Por. O. KNocH, dz. cyt., 91.

33 Por. B. Szczepanowicz, Atlas roślin biblijnych. Pochodzenie, miejsce w Biblii i symbolika, Kraków 2003, 169n; J.I. Packer - M.C. Tenney, dz. cyt., 204.

34 Por. J. Gnilka, dz. cyt., 187 n.

35 R. PESCH, dz. cyt., 252.

36 Por. C.S. Keener, dz. cyt., 90.

37 Por. A. Smitmans, Przypowieść o ziamie gorczycy, w: A. Grabner-Haider (red.), Praktyczny Stownik Biblimy, Warszawa 1994, 1096; E. SCHWEITZER, dz. cyt., 53. 


\subsection{Przypowieść o chwaście (Mt 13,24-30)}

Jedynie ewangelista Mateusz przekazuje tę przypowieść, którą należy zaliczyć do paraboli, ponieważ w czasach Jezusa było powszechną praktyką pielenie chwastu przed żniwami; zakaz tego byłby czymś nienormalnym ${ }^{38}$. Jezus wykorzystując ekologiczny obraz siewu i żniwa mówi o losie dobrego ziarna, które ma wzrastać wśród chwastów aż do czasu żniwa. Dopiero wtedy okaże się, który zasiew zwycięży. Jezus odpowiada tu na pytanie uczniów, jak mają się zachować wobec chwastów do czasu nadejścia sądu ostatecznego, kiedy to objawi się w pełni królestwo Boże ${ }^{39}$.

Występowanie chwastu wśród pszenicy nie jest niczym nadzwyczajnym. W przypowieści chodzi jednak o to, że tego chwastu było niesłychanie dużo. To, że słudzy gospodarza dostrzegli ten chwast tak późno, jest związane z tym, że był to trujący chwast w rodzaju perzu, życica roczna, która gdy jest mała wygląda bardzo podobnie jak pszenica ${ }^{40}$. Również złośliwe posianie nocą chwastu na polu sąsiada, którego się nienawidziło, nie należało w Palestynie i w Egipcie do rzadkości. Właściciel zachwaszczonego pola wiedział też od razu, że jest to sprawa jego wroga ${ }^{41}$. Propozycja sług, aby wypielić chwast jest jak najbardziej zrozumiała - tak czynili wszyscy. Odpowiedź gospodarza, który karze sługom czekać do żniwa jest dla nich zupełnie niezrozumiała. Żniwo jest w przypowieści Jezusa, podobnie jak już w Starym Testamencie (np. Iz 17,5; Joel 4,13), metaforą sądu ostatecznego (por. też Mt 3,12; Mk 4,29; Ap 14,14-20) 42. Do żniwa zatrudnia-

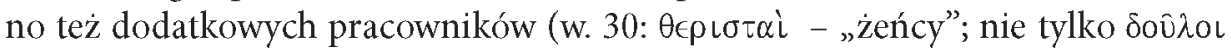
- „słudzy” jak w w. 27 i 28), którzy oddzielali chwast od pszenicy kładąc go na ziemi. Po zebraniu i powiązaniu w snopki pszenicy, zbierano i wiązano również chwast, który służył w ubogiej w drzewa Palestynie jako materiał do spalenia ${ }^{43}$.

Po odprawieniu tłumów Jezus na prośbę uczniów wyjaśnia im przypowieść o chwaście (Mt 13,36-43), tzn. odkrywa rzeczywistość rzeczową przypowieści. „Tym, który sieje dobre nasienie, jest Syn Człowieczy. Rolą jest świat, dobrym nasieniem są synowie królestwa, chwastem zaś synowie Złego. Nieprzyjacielem, który posiał chwast, jest diabeł; żniwem jest koniec świata, a żeńcami są aniołowie" (w. 37-39). Jezus mówiąc o nagrodzie dla sprawiedliwych nawiązuje wyraźnie do Dn 12,34. Opisując sytuację swoich uczniów w świecie wzywa ich do

38 Por. U. Luz, Das Evangelium nach Matthäus. 2.Teilband. Mt 8 - 17 (EKK I/2), Zürich Braunschweig - Neukirchen-Vluyn 1990, 321-323.

39 Por. J. GNILKa, Das Matthäusevangelium. Erster Teil. Einleitung und Kommentar zu Kapitel 1,1 - 13,58 (HThK.NT I/1), Freiburg - Basel - Wien ${ }^{3} 1993,489$ n.

${ }^{40}$ Por. B. Szczepanowicz, dz. cyt., $236 \mathrm{n}$.

41 Por. C.S. Keener, dz. cyt., 39.

42 Por. L. Rycken - J.C. Wilhoit - T. Longmann III, dz. cyt., 1209-1211.

43 Por. U. Luz, dz. cyt., 324n.

${ }^{44}$ E. SchweIzer, Das Evangelium nach Matthäus (NTD 2), Göttingen - Zürich ${ }^{16} 1986,202$. 
zaufania Bogu i do cierpliwości oraz napomina ich, aby nie nadużywali pobłażliwości i cierpliwości Boga ${ }^{45}$.

\subsection{Przypowieść o nieurodzajnym figowcu (Łk 13,6-9)}

Przypowieść ta należąca do materiału własnego Łukasza jest paraboląa ${ }^{46}$, ponieważ prośba ogrodnika, aby przesunąć o rok decyzję o wycięciu nieurodzajnego figowca jest czymś niezwykłym ${ }^{47}$. Wprawdzie obraz nieurodzajnego drzewa figowego jako metafora na określenie niewiernego Izraela występuje także u Marka (Mk 11,12-14.20-25) i u Mateusza (Mt 21,18-22), ale nie są to przypowieści. Łukasz opuszcza tamten opis znajdujący się u pozostałych synoptyków, ponieważ zamieszcza przypowieść o nieurodzajnym figowcu ${ }^{48}$.

Figowce, które przy dobrej wilgotności rosły także na podłożu skalistym, sadzono często w Palestynie także w winnicach. W gorące letnie popołudnia szukano chętnie schronienia w cieniu figowca (por. $1 \mathrm{Krl} 5,5$; Mi 4,4; J 1,48). Miejsce w winnicy o urodzajnej glebie było dla figowca faworyzowaniem. Wg starotestamentalnych przepisów (Kpl 19,23) dopiero od czwartego roku zrywano $\mathrm{z}$ młodego figowca owoce ${ }^{49}$. W związku z tym, że właściciel winnicy już trzy lata przychodzi i na próżno szuka na figowcu owoców, oznacza to, że minęło już sześć lat od zasadzenia drzewa. Figowiec w Palestynie dwa razy w roku rodził owoce, w czerwcu soczyste, zielone wczesne figi oraz w sierpniu niebieskie, słodkie figi letnie. Figi stanowiły wówczas jeden z głównych składników pożywienia ludzi. Winnice były wtedy rzadko nawożone, a figowce w ogóle. Stąd propozycja ogrodnika, że okopie i obłoży nawozem drzewo figowe brzmi niebywale ${ }^{50}$.

Figowiec, o którym mówi Jezus w przypowieści, jest zupełnie nieurodzajnym drzewem. Próby ogrodnika, aby mimo trzy- czy czteroletniego braku owoców, drzewo rodziło owoc, są czymś wyjątkowym i pokazują, że dla drzewa i jego przyszłości zrobiono wszystko. Na uwagę zasługuje też niesłychanie cierpliwy właściciel winnicy, który mimo zwątpienia pozwala zostawić drzewo jeszcze na rok. Jeżeli nie przyniesie owocu, wtedy będzie wycięte ${ }^{51}$.

45 Por. O. KNoch, dz. cyt., 108 n.

46 Por. H. Zimmermann, dz. cyt., 146n.

${ }^{47}$ Por. J. Ernst, Das Evangelium nach Lukas (RNT), Regensburg 1977, 285. O. KNocH, dz. cyt., 133.

48 Por. P.G. Müller, Lukas-Evangelium (SKK.NT 3), Stuttgart 1984, 126.

49 Por. B. Szczepanowicz, dz. cyt. 37-41; M. Lurker, Slownik obrazów i symboli biblijnych, Poznań 1989, 55n.

50 Por. C.S. KeEner, dz. cyt., 156.

51 Por. J.A. Martin, Lukas, w: J.F. Walvoord - R.B. Zuck (red.), Das Neue Testament erklärt und ausgelegt. Band 4. Matthäus - Römer, Holzgerlingen ${ }^{3} 2000,303$. 
Przy pomocy ekologicznego obrazu Jezus przestrzega przed niebezpieczeństwem braku duchowych owoców i poucza, ze rozpoczęty wraz z Jego działalnością na ziemi czas łaski jeszcze trwa ${ }^{52}$. Boża propozycja zbawienia jest wciąż aktualna, choć naród wybrany, reprezentowany poprzez swoich przywódców, jeszcze jej nie przyjął. Owoce nawrócenia, wiary w posłannictwo Jezusa i przyjęcie darów zbawczych jeszcze nastąpi. Na prośbę Jezusa Bóg przedłuża czas łaski, aby dać Izraelowi ostatnią szansę do nawrócenia ${ }^{53}$.

\subsection{Przypowieść o figowcu (Mk 13,28-29; Mt 24,32-33; Lk 21,29-31)}

Przypowieść ta, odnotowana przez wszystkich synoptyków, jest przypowieścią właściwą. Jezus naucza o królestwie Bożym biorąc za przykład drzewo figowe. W odróżnieniu od innych drzew Palestyny figowiec traci jesienią liście i wygląda jak uschły. Gdy rozpoczyna się ciepła i sucha pora roku figowiec nabrzmiewa i wypuszcza liście oznaczając początek lata ${ }^{54}$. Już u proroka Joela $(2,22)$ czas zbawienia opisany jest słowami: „drzewo figowe i krzew winny plon przynoszą" (por. Jer 8,13). Jezus wykorzystując obraz figowca mówi o rozpoczętym poprzez swoją działalność czasie zbawienia. Jak liście i gałązki figowca wskazują na początek lata, tak Jego działanie wskazuje na bliski początek Bożego panowania (por. Łk 12,54-57)

\subsection{Przypowieść o przewrotnych rolnikach (Mk 12,1-12; Lk 20,9-19; Mt 21,33-46)}

Przypowieść tę należy zaliczyć do paraboli, ponieważ odmowa zapłaty za dzierżawę przez dzierżawców, jak również próba przejęcia winnicy na własność poprzez zamordowanie syna właściciela byly nawet $\mathrm{w}$ tamtych warunkach $\mathrm{w} \mathrm{Ga}-$ lilei czymś nieprawdopodobnym ${ }^{56}$. Jezus próbuje skłonić przywódców narodu wybranego do przyjęcia zbawczej propozycji Boga i uznania Jego posłannictwa. Odwołuje się przy tym do dobrze znanego Żydom starotestamentalnego obrazu winnicy, w którym Izrael jest winnicą bądź krzewem winnym Jahwe (por. Iz 5,1n; $\mathrm{Oz} 10,1 ;$ Jer 2,$21 ; 12,10$; Ps 80,9-17) ${ }^{57}$. Centrum przypowieści stanowi zachowanie dzierżawców właściciela winnicy. Jezus posługując się ekologicznym obrazem winnicy opisuje tu przede wszystkim troskę Boga o naród wybrany.

52 Tak O. KNoch, dz. cyt., 134.

53 Por. E. Schweizer, Das Evangelium nach Lukas (NTD 3), Göttingen ${ }^{20} 1993,145$.

54 Por. C.S. KeEner, dz. cyt., 112 n.

s5 Por. R. Pesch, Das Markusevangelium. Zweiter Teil. Einleitung und Kommentar zu Kapitel 8,27 - 16,20 (HThK.NT II/2), Freiburg - Basel - Wien ${ }^{4} 1991,307 \mathrm{n}$.

56 Tak O. KNoch, dz. cyt., 151.

${ }^{57}$ Por. L. Ryken - J.C. Wilhoit - T. Longman III, dz. cyt., 1093-1096. 
Założenie winnicy wymagało w górzystej Palestynie wiele pracy i nakładów. Konieczny był płot, często kamienny mur, aby chronił winnicę przed zwierzętami i złodziejami. Od razu też należało wykopać tłocznię. Wieża wartownicza lub domek były ciągle wykorzystywane szczególnie $w$ okresie dojrzewania owoców, gdyż w czasie winobrania mieszkano w winnicy, aby bronić zbiorów przed złodziejami ${ }^{58}$. W czasach Jezusa duża część gruntów w Galilei znajdowała się w rękach króla, który przekazywał je urzędnikom i przyjaciołom oraz w rękach wielkich posiadaczy ziemskich, często obcokrajowców, którzy poprzez swoich urzędników zarządzali gruntami i winnicami, oddając je zazwyczaj w dzierżawę miejscowym rolnikom czy winiarzom za pokaźną część zysku. Niechęć płacenia i krnąbrność dzierżawców, nierzadko nastawionych rewolucyjnie zelotów, zdarzała się wówczas dość często, jak również zwymyślania, pobicia i wyrzucenia sług, którzy przybywali po odbiór należnej dzierżawy ${ }^{59}$. Pierwszy termin zapłaty dzierżawy następował wg Kpł 19,23-25 w piątym roku po posadzeniu drzew, krzewów czy winnych latorośli ${ }^{60}$. Dzierżawcy z przypowieści traktują cierpliwość i dobroć właściciela winnicy, który zamiast zareagować przy pomocy miejscowych sił porządkowych posyła do nich kolejne sługi, jako jego słabośćct ${ }^{61}$.

Jezus stawiając pytanie o los dzierżawców odpowie zaraz, że właściciel winnicy przyjdzie i wytraci rolników, a winnicę odda innym w dzierżawę. Chce poprzez tę przypowieść sprowokować przywódców narodu wybranego do zastanowienia i ponownego przemyślenia następstw ich postępowania: odrzucenie Izraela, utrata wybraństwa Bożego i oczekiwanie na pełnię zbawienia ${ }^{62}$. Słuchacze zrozumieli dokładnie metaforyczny język Jezusa. „Starali się Go ująć, lecz bali się tłumu" (Mk 12,12) ${ }^{63}$.

\subsection{Przypowieść o robotnikach w winnicy (Mt 20,1-16)}

Przypowieść ta, która występuje tylko u Mateusza jest parabolą odpowiadającą na pytanie o relację między ludzkimi dokonaniami a Bożą zapłatą. Dwa momenty są tu bardzo istotne: zwerbowanie robotników do pracy i umówienie się na zapłatę oraz zapłata i rozmowa, która się przy tym wywiązała ${ }^{64}$. Jezus nawiązuje w przypowieści do ówczesnych typowych dla Palestyny warunków pracy.

58 Por. C.S. KeEner, dz. cyt., 108.

59 Por. O. KNoch, dz. cyt., 153.

${ }^{60}$ Por. J.I. PACKer - M.C. Tenney, dz. cyt., 220.

61 Por. J. GNil.Ka, Das Evangelium nach Markus. 2.Teilband. Mk 8,27 - 16,20 (EKK II/2), Zürich - Einsiedeln - Köln - Neukirchen-Vluyn 1979, 145n.

62 Por. R. Pesch, Mk II 221-223; E. Schweizer, Mk 132n.

${ }_{63}$ Por. K. Kertelge, dz. cyt., 117.

${ }^{64}$ Por. J. Gnilka, Das Matthäusevangelium. Zweiter Teil. Einleitung und Kommentar zu Kapitel 14,1 - 28,20 (HThK.NT I/2), Freiburg - Basel - Wien ${ }^{2} 1992,175$. 
W czasie zbiorów winogron, który rozpoczynał się w sierpniu, właściciel winnicy na początku dnia szedł na rynek, gdzie gromadzili się wolni pracownicy i najemnicy. Po uzgodnieniu zapłaty właściciel posyłał ich do swojej winnicy do pracy. Normalną stawką za dzień pracy był wtedy jeden denar (por. Ap 6,6), który na żądanie robotnika musiał być wypłacony wieczorem (por. Kpł 19,13; Pwt $24,14)^{65}$. Dzień pracy, który trwał od wschodu aż do zachodu słońca, byl podzielony na dwanaście „godzin”. Zatrudniał, rozdzielał pracę, pilnował i wypłacał zazwyczaj zarządca. W przypowieści czyni to sam właściciel winnicy ${ }^{66}$. Siła robocza była w Palestynie tania. Jeden denar wystarczał na dzienne wyżywienie nawet ośmioosobowej rodziny. Niezrozumiałe więc jest, dlaczego właściciel winnicy nie zatrudnił od razu wystarczającej liczby robotników, lecz przychodził ciągle na nowo na rynek i zatrudniał wszystkich bezrobotnych ${ }^{67}$.

Jezus przedstawiając $w$ przypowieści o robotnikach $w$ winnicy Boży sposób działania i wynagradzania weryfikuje judaistyczno-faryzejskie przekonanie, że Bóg odpłaca ściśle według dokonań ludzkich ${ }^{68}$. Jezus wprowadza przy tym element współczucia i miłosierdzia ${ }^{69}$. Właściciel winnicy daje każdemu tę samą zapłatę, niezależnie od tego ile godzin pracował. Tak jak właściciel winnicy postępuje Bóg - wyjaśnia Jezus i ogłasza orędzie o dobroci Bożej ${ }^{70}$.

\section{Znaczenie ekologii w przypowieściach}

Obrazy i sytuacje, które Jezus przedstawia w przypowieściach, często nawiązują do ekologii. Odwołując się do znanej i tak bliskiej każdemu człowiekowi dziedziny życia, Jezus chce być właściwie zrozumiany przez swoich słuchaczy, gdy wyjaśnia trudne prawdy swego nauczania. W przypowieściach o siewcy (Mk 4,1-9; Mt 13,1-9; Łk 8,4-8), o zasiewie (Mk 4,26-29) i o ziarnku gorczycy (Mk 4,30-32; Mt 13,31n; Łk 13,18n) opisuje początek, rozwój i rzeczywistość Królestwa Bożego, które zapoczątkował na ziemi. W przypowieści o figowcu (Mk 13,28-29; Mt 24,32-33; Łk 21,29-31) Jezus wyjaśnia, że rozpoczął się już czas zbawienia i panowania Bożego. O sytuacji zaś uczniów w świecie, którzy żyją wśród nieprzyjaciół aż do końca świata, traktuje przypowieść o chwaście (Mt 13,24-30).

\footnotetext{
65 Por. C.S. KeEner, dz. cyt., 52 n.

66 Por. J. Gnilka, Mt II 177.

${ }^{67}$ Por. O. KNoch, dz. cyt., 203 n.

68 Por. E. Schweitzer, Mt 257n; E. Beck, Przypowieść o winnicy, w: A. Grabner-Haider (red.), Praktyczny Słownik Biblijny, Warszawa 1994, 1095n.

69 Por. J. GnIlKa, Mt II 179. O. KNoch, dz. cyt., 203n;

70 Por. L.A. Barbieri, Matthäus, w: J.F. Walvoord - R.B. Zuck (red.), Das Neue Testament erklärt und ausgelegt. Band 4. Matthäus - Römer, Holzgerlingen ${ }^{3} 2000,71$.
} 
Jezus wzywa też do nawrócenia i wydawania duchowych owoców, wskazując przy tym na cierpliwość Boga, gdy opowiada przypowieść o nieurodzajnym figowcu (Łk 13,6-9). Niewdzięczność ludzka i przede wszystkim postępowanie Izraela wobec Boga i Jego proroków przedstawione są w przypowieści o przewrotnych rolnikach (Mk 12,1-12; Łk 20,9-19; Mt 21,33-46). Dobroci, miłosierdziu i niepojętej dla ludzi ekonomii Bożej poświęcona jest przypowieść o robotnikach w winnicy (Mt 20,1-16).

Wszystkie przypowieści Jezusa wskazują na nową sytuację człowieka i narodu wybranego wobec objawiającego się Boga, która powstała wraz z przyjściem Chrystusa. Jezus pragnie obdarzyć wszystkich ludzi swoim miłosierdziem i dać im swoje zbawienie. Jego zadaniem jest zwrócenie uwagi słuchaczy na rozpoczętą przez Niego nową rzeczywistość zbawczą i wezwanie wszystkich ludzi do udziału w Bożym planie zbawienia świata ${ }^{71}$. W realizacji tego zadania szczególną rolę odgrywają przypowieści, a wśród nich te, które wykorzystują obrazy i motywy z zakresu ekologii.

\title{
Ecology in the Parables of Jesus
}

\author{
SUMMARY
}

Jesus during His public ministry concentrated Himself above all on teaching. He often made use of parables, in which He used a variety of motifs and presentations from the field of ecology, in order to be properly understood by His listeners. Making use of ecological images Jesus describes the beginning, development and reality of the Kingdom of God, He speaks about the time already begun of salvation and God's reign, about God's goodness and mercy, about the situation of His disciples in the world. He also calls for repentance and for the bearing of good fruit.

71 Por. O. KNOCH, dz. cyt., 34n. 